\title{
ХВОРОБА, ВИКЛИКАНА ВІРУСОМ ЕБОЛА: ОСОБЛИВОСТІ РОБОТИ МЕДИЧНОЇ СЕСТРИ ЩОДО ПРОФІЛАКТИКИ ЗАВЕЗЕННЯ І РОЗПОВСЮДЖЕННЯ
}

\author{
А. М. Савич, В. О. Качор \\ Ужгородська обласна клінічно-інфекційна лікарня \\ ДВНЗ «Тернопільський державний медичний університет імені І. Я. Горбачевського \\ МОЗ України»
}

У статті наведено сучасні дані щодо догляду за пацієнтами з хворобою, викликаною вірусом Ебола, представлено рекомендації стосовно ї̈ лікування та профілактики та визначено особливості тяжких форм і ускладнень.

\section{DISEASE CAUSED BY EBOLA VIRUS: FEATURES OF NURSING WORK IN PROPHYLAXIS OF DELIVERY AND DISTRIBUTION}

\author{
A. M. Savitch, V. O. Kachor \\ Uzhorod Regional Clinical Infectious Hospital \\ SHEI "Ternopil State Medical University by I. Ya. Horbachevsky of MPH of Ukraine»
}

The modern data about nursing of patients with disease caused by Ebola virus is given. The proved recommendations on therapy and prophylaxis are submitted. The features of severe forms and complications are considered.

Вступ. Цього року людство спіткала чергова катастрофа - виникла епідемія висококонтагіозної вірусної геморагічної гарячки Ебола, яка належить до особливо небезпечних (карантинних) інфекцій. Недуга ендемічна для певних місцевостей Африки. Перші випадки гарячки Ебола було зареєстровано в 1976 р. у Судані (захворіло 284 людини, померло 151, летальність 53,2 \%) і в Конго у селищі Ямбуку (відповідно, 318, 280, 88 \%) поблизу р. Ебола; у подальшому епідемії реєструвались у Кенії та деяких інших країнах Західної і Центральної Африки. Остання епідемія почалась у Гвінеї у лютому 2014 р. ВООЗ оголосила епідемію катастрофою міжнародного рівня, за прогнозами вона буде продовжуватись щонайменше до початку 2015 р. Станом на 08.01.2015 р. зафіксовано понад 8 тисяч випадків гарячки Ебола,

(C) A. М. Савич, В. О. Качор, 2015
3 яких загиблих - 4,818 осіб у 8 країнах. Цьогорічна епідемія в Західній Африці визнана найтяжчою за весь період спостережень за хворобою. Випадки недуги зареєстровано в Гвінеї, Сьерра-Леоне, Ліберії, Нігерії, Сенегалі, Демократичній Республіці Конго [1].

$€$ випадки завезення гарячки Ебола в країни Америки і Європи хворими приматами і людьми, які перебували в інкубаційному періоді. Зафіксовано поодинокі випадки хвороби або підозри на неї серед прибулих із Західної Африки в США, Англію, Німеччину, Канаду; 12.08 зареєстровано перший в Європі випадок смерті від гарячки Ебола священика, який прибув у Іспанію з Ліберії.

Основна частина. Джерелом збудника $є$ щури, примати, а також людина. Природний резервуар - плодоїдні летючі миші родини Pteropodidae. Механізм передачі вірусу контакт- 
ний, можливе поширення його від людини до людини при тісному контакті через рідини і секрети, недостатньо простерилізований інструментарій, а також аерогенним шляхом, через статеві стосунки. Вірус виділяеться від хворих впродовж близько 3 тижнів, іноді до 2 місяців [2].

Інкубаційний період триває від 2 до 21 дня. Гарячка Ебола зазвичай починається гостро 3 підвищення температури тіла, симптомів вираженої інтоксикації, сильного головного болю, болю у суглобах, м'язах. Дещо пізніше з'являється сухий кашель, сухість і першіння в горлі, колючий біль у грудній клітці. На 2-3 день хвороби виникають біль у животі, нудота, діарея, внаслідок якого швидко розвивається дегідратація. У половини пацієнтів на 4-5 день хвороби 3'являється плямисто-папульозна висипка спочатку на обличчі, потім на грудній клітці, яка здатна поширюватися й на інші частини тіла. При огляді хворого відзначають гіперемію кон'юнктив, глибоко запалі очі, нерухоме обличчя, загальмованість. На 2 тижні недуги часто виникають кровотечі, шок, набряк легень, які $€$ причиною високої летальності [3].

Підходи до лікування такі ж, як при інших геморагічних гарячках. Специфічної терапії не розроблено. Патогенетичне лікування спрямоване на зменшення явищ інтоксикації, дегідратації, геморагічних проявів, усунення розладів гемодинаміки, боротьбу з геморагічним шоком, ННГМ, іншими проявами хвороби.

На сьогодні рекомендовано застосувати певні етіотропні експериментальні ліки, які ще не мали повноцінного попереднього вивчення, як це відбувається при введенні до обігу комерційних лікарських препаратів у світі. Обговорювалась потенційна ефективність для лікування гарячки Ебола плазми реконвалесцентів і гіперімунного імуноглобуліну, моноклональних антитіл у препаратах Zmapp, ZMAb, малихінгібуючих PHK у препараті siRNA, противірусних препаратів Фавіпіравір, Бринцидофовір, Тореміфін, Аміодарона, інтерферонів. Поки що аналізувати ефективність цих препаратів важко [4].

Профілактика проводиться як і при інших геморагічних гарячках.

При відвідуванні країн, де має місце епідемія хвороби, викликаної вірусом Ебола, необхідно дотримуватись таких рекомендацій:

- часто мити руки;

- уникати контакту з кров'ю і біологічними рідинами людини, особливо хворих;

- не торкатися тіл померлих від хвороби, викликаної вірусом Ебола;

- не вживати м'яса летючих мишей і приматів, не торкатися до їх крові і рідин;
- уникати потрапляння у лікарню, де лікуються паціенти $з$ хворобою, викликаною вірусом Ебола;

- у випадку появи гарячки (температура тіла вища $38,6{ }^{\circ} \mathrm{C}$ ) і будь-якого із таких симптомів, як біль в м'язах, животі, головний біль, діарея, блювота, підшкірні крововиливи або кровотеча, необхідно відразу звернутись за медичною допомогою;

- обмежити контакти 3 іншими людьми до огляду медичного працівника.

Після повернення із країн підвищеного ризику потрібно звертати увагу на свій стан здоров'я впродовж 21 дня, а у випадку появи вищеперерахованих симптомів необхідно відразу звернутись за медичною допомогою телефоном, акцентувавши про перебування в країнах Західної Африки.

Випадки захворювання або завезення хвороби, викликаної вірусом Ебола, на територію України не зафіксовано, однак враховуючи сучасні засоби комунікації відкинути такий ризик неможливо жодній країні світу. Тому медичним працівникам всіх ланок охорони здоров'я потрібно бути насторожі. Оскільки значне число прибулих в Україну із країн Західної Африки студенти, доцільно комплекс протиепідемічних заходів у кожному обласному центрі спрямувати саме на цю групу осіб:

- уточнення списків студентів, які мають прибути із країн Західної Африки в кожному вищому навчальному закладі (прізвище, дата народження, курс, група);

- інформація щодо прибуття (дата, місце проживання);

- організація медичного огляду лікаремінфекціоністом у день прибуття;

- збір епіданамнезу (день вибуття з країни, транспорт на якому прибули, дата прибуття в Україну, дата прибуття в населений пункт);

- організація медичного спостереження протягом 21 дня 3 моменту виїзду з рідної країни (щоденно - середнім медпрацівником, 1 раз на тиждень лікарем).

3 метою уникнення поширення інфекції доцільно організувати проживання прибулих студентів у межах інкубаційного періоду в одному гуртожитку. Провести роз'яснювальну роботу серед прибулих студентів щодо клінічних ознак хвороби, обов'язковості звернення за медичною допомогою, достовірності інформації про перебування за кордоном [5].

Хворі на гарячку Ебола підлягають негайній госпіталізації в бокси відділення із збереженням суворого режиму, який рекомендується у випадках хвороб, що підлягають регуляції ММСП 2005 р. Медичний персонал повинен працюва- 
ти в максимально захищеному вологонепроникному одязі (щоби не просякала кров) із збереженням суворих бар'єрних методів захисту. Необхідно також приділяти особливу увагу належному знезараженню медичних відходів і біологічних рідин хворих. Реконвалесцентів виписують не раніше 21 дня при негативних результатах вірусологічних досліджень за умови повного клінічного одужання. У епідемічних ситуаціях проводять посилений нагляд і активне виявлення усіх підозрілих і ймовірних випадків із негайною ізоляцією хворих, а також усіх людей, які контактували з ними для щоденного медичного спостереження. Зона нагляду повинна залишатись під контролем протягом двох інкубаційних періодів після останнього летального випадку або після виписки останнього хворого. Важливим профілактичним за-

\section{ЛITEPATУРA}

1. uk.wikipedia.org/.

2.http://www.ncbi.nlm.nih.gov/pubmed/25260583.

3. http://www.amnu.gov.ua./articles

4. Мальй В. П. Болезнь, вызванная вирусом Эбола: клиника, диагностика, печение, профилактика / В. П. Малый. - Харьков, 2014. - 23 с. ходом, що перешкоджає завезенню гарячки із ендемічних районів, є здійснення Міжнародної системи епідеміологічного нагляду, проведення протиепідемічних заходів, передбачених ММСП 2005 p.

Специфічна профілактика натепер перебуває у стадії розробки. На шляху до впровадження у широку медичну практику дві перспективні вакцини: ChAd3-ZEBOV i rVSV-ZEBOV.

Висновки. За відсутності засобів специфічної профілактики і дієвого етіотропного лікування підвищення поінформованості населення щодо факторів ризику інфікування вірусом Ебола, перших ознак недуги і використання індивідуальних заходів захисту, ретельне динамічне медичне спостереження за прибулими з неблаго получних районів - единий шлях запобігання завезенню і розповсюдженню недуги.

5. Качор В. О. ГарячкаЕбола: заходи з профілактикиз завозу і розповсюдження / В. О. Качор, О. Л. Івахів, О. Р. Голик / / Фармакотерапія іпрофілактика інфекційних та паразитарних хвороб : зб. матеріалів Всеукр. інтернет-конф., жовтень 2014 р. - Тернопіль : ТДМУ, Укрмедкнига, 2014. - С. 96-99.

Отримано 18.12.14 